\title{
USE OF LARSON-MILLER PARAMETER FOR MODELING THE PROGRESS OF ISOTHERMAL SOLIDIFICATION DURING TRANSIENT-LIQUID-PHASE BONDING OF IN718 SUPERALLOY
}

\author{
UPORABA LARSON-MILLERJEVEGA PARAMETRA ZA \\ MODELIRANJE IZOTERMNEGA STRJEVANJA PRI SPAJANJU Z \\ VMESNO TEKOČO FAZO SUPERZLITINE IN718
}

\author{
Majid Pouranvari'1, Seyed Mostafa Mousavizadeh ${ }^{2}$ \\ ${ }^{1}$ Materials and Metallurgical Engineering Department, Dezful Branch, Islamic Azad University, Dezful, Iran \\ ${ }^{2}$ Department of Materials Engineering, Faculty of Engineering, Hakim Sabzevari University, Sabzevar, Iran \\ mpouranvari@yahoo.com \\ Prejem rokopisa - received: 2014-03-10; sprejem za objavo - accepted for publication: 2014-05-09
}

doi:10.17222/mit.2014.048

\begin{abstract}
The progress of diffusion-induced isothermal solidification, which is a vital issue in transient-liquid-phase bonding, is modeled using the Larson-Miller parameter $(L M P)$. The solidification mechanisms of the liquid phase during the TLP bonding of a wrought IN718 nickel-based superalloy with different bonding times/temperatures and the data were analyzed using the Larson-Miller parameter. Based on the Larson-Miller parameter $(L M P)$, the TLP bonding parameter was defined in the form of $L M P=T_{\mathrm{B}}\left[70+\ln \left(t_{\mathrm{B}}\right)\right]$ to explore the effects of the bonding temperature $\left(T_{\mathrm{B}}\right)$ and the bonding time $\left(t_{\mathrm{B}}\right)$ on the isothermal solidification progress. It was found that there is a direct linear relationship between the $L M P$ and the isothermal-solidificationzone size.

Keywords: transient-liquid-phase bonding, isothermal solidification, superalloy, Larson-Miller parameter
\end{abstract}

Napredovanje z difuzijo spodbujenega izotermnega strjevanja, ki je vitalen del spajanja z vmesno tekočo fazo, je modelirano $z$ uporabo Larson-Millerjevega parametra $(L M P)$. Mehanizem strjevanja tekoče faze med TLP-spajanjem superzlitine IN718 na osnovi niklja pri različnih časih/temperaturah ter podatki so bili analizirani z uporabo Larson-Millerjevega parametra. Na tej podlagi je bil določen parameter TLP-spajanja v obliki $L M P=T_{\mathrm{B}}\left[70+\ln \left(t_{\mathrm{B}}\right)\right]$, da bi ugotovili vpliv temperature spajanja $\left(T_{\mathrm{B}}\right)$ in časa spajanja $\left(t_{\mathrm{B}}\right)$ na napredovanje izotermnega strjevanja. Ugotovljeno je bilo, da obstaja neposredna linearna odvisnost med $L M P$ in velikostjo področja izotermnega strjevanja.

Ključne besede: spajanje s prehodno tekočo fazo, izotermno strjevanje, superzlitina, Larson-Millerjev parameter

\section{INTRODUCTION}

Nickel-based superalloys are extensively used in the modern industry due to their excellent high-temperature tensile strength, stress rupture and creep properties, fatigue strength, oxidation and corrosion resistance and microstructural stability at elevated temperature ${ }^{1-3}$.

Transient-liquid-phase (TLP) bonding is considered as an interesting repairing/joining process for nickelbased superalloys due to its ability to produce near-ideal joints ${ }^{4}$. In the TLP bonding, by placing a thin filler alloy (i.e., interlayer) of an alloying metal containing a melting-point-depressant (MPD) element between the two pieces of the base metal to be joined and heating the entire assembly, a liquid phase is formed ${ }^{5}$. The diffusion of the melting-point depressants (MPD) from the molten interlayer into the base metal causes significant compositional changes in the liquid phase and increases the liquidus temperature of the liquid phase. Once the liquidus temperature reaches the bonding temperature, isothermal solidification starts. As a result of the absence of a solute rejection at the solid/liquid interface during the isothermal solidification, the formation of the second phase is basically prevented and a single-phase microstructure is formed in the ISZ. If a sample is cooled down before the completion of isothermal solidification, the residual liquid will be solidified during the cooling. A non-equilibrium segregation of the MPD elements results in a formation of eutectic-type solidification products consisting of hard and brittle intermetallic pha$\operatorname{ses}^{6-9}$. Therefore, there is a critical bonding time $\left(t_{\mathrm{IS}}\right)$ beyond which the formation of a eutectic-type microstructure in the joint centerline is precluded (i.e., the entire liquid phase is solidified isothermally).

In their studies of the effects of the stress and temperature on the creep-rupture time of gas-turbine alloys, Larson and Miller ${ }^{10}$ showed that their results could be collapsed onto a common curve using a normalization of the following form: $L M P=T[C+\operatorname{Ln}(t)]$. This normalization has been widely used since as a phenomenological method to relate the effects of the time and temperature on various thermally activated processes (for example $\left.{ }^{11,12}\right)$. Since the isothermal solidification process is the key stage of the TLP bonding, this paper aims at investigating the application of the Larson-Miller parameter to modeling the progress of isothermal solidifi- 


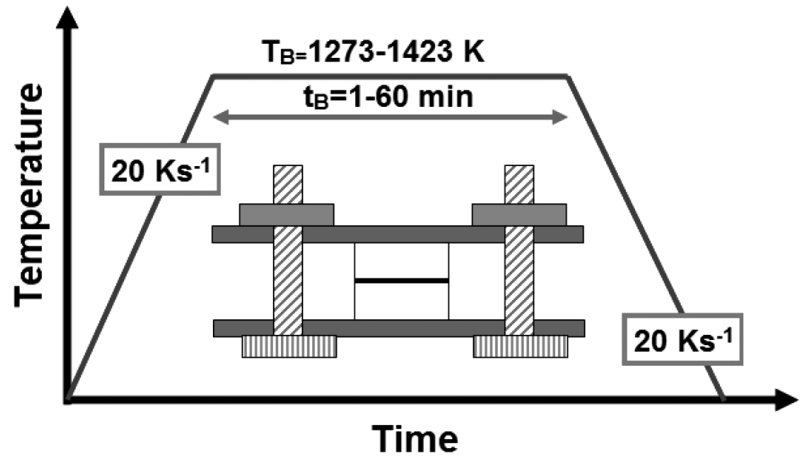

Figure 1: Temperature-time history during the TLP bonding of the IN718 alloy. The fixture used to hold the samples during the bonding is also superimposed in the figure.

Slika 1: Temperaturna in časovna odvisnost med TLP-spajanjem zlitine IN718. Prikazano je tudi uporabljeno držalo vzorcev med spajanjem.

cation during the transient-liquid-phase bonding of a superalloy.

\section{EXPERIMENTAL PROCEDURE}

The wrought IN718 nickel-based superalloy (Ni-20.26Fe-18.23Cr-4.85 Nb-3.10Mo-0.93 Ti-0.61 Al-0.19Si $(w / \%))$ was TLP bonded using a $50 \mu \mathrm{m}$ thick BNi-2 (Ni-7Cr-4.5Si-3.2B-3Fe). $10 \mathrm{~mm} \times 5 \mathrm{~mm} \times 5 \mathrm{~mm}$ coupons were sectioned from the base metal using an electro-discharge machine. Thereafter, in order to remove the oxide layer, the contacting surfaces were ground using 600-grade SiC paper and then ultrasonically cleaned in an acetone bath. The interlayer was then inserted between the two base-metal coupons. A Cr-Mo steel fixture (Figure 1) was used to fix the coupons in order to hold this sandwich assembly and reduce the metal flow during the TLP operation. Figure 1 shows the thermal history during the bonding of the samples. The bonding was carried out in a furnace at the temperatures of $(1273,1323,1373$ and 1423) K under a vacuum of approximately $1.33 \cdot 10^{-5} \mathrm{mbar}$. The bonding time was varied from 1-60 min.

The bonded specimens were sectioned perpendicular to the bond and then microstructural observations of the cross-sections of the specimens were carried out using a light microscope and a field-emission scanning electron microscope (FESEM). For the microstructural examinations, the specimens were etched using a solution containing $10 \mathrm{~mL}$ of $\mathrm{HNO}_{3}, 10 \mathrm{~mL}$ of $\mathrm{C}_{2} \mathrm{H}_{4} \mathrm{O}_{2}$ and $15 \mathrm{~mL}$ of $\mathrm{HCl}$. Semi-quantitative chemical analyses of the phases formed in the centerline of the bond region and adjacent to the base metal were conducted with a JEOL 5900 FESEM equipped with an ultra-thin-window Oxford energy-dispersive X-ray spectrometer (EDS).

\section{RESULTS AND DISCUSSION}

\subsection{Microstructure evolution during isothermal solidi- fication}

Figure 2a depicts a typical microstructure of TLP bonded IN718 using a Ni-7Cr-4.5Si-3.2B-3Fe filler alloy
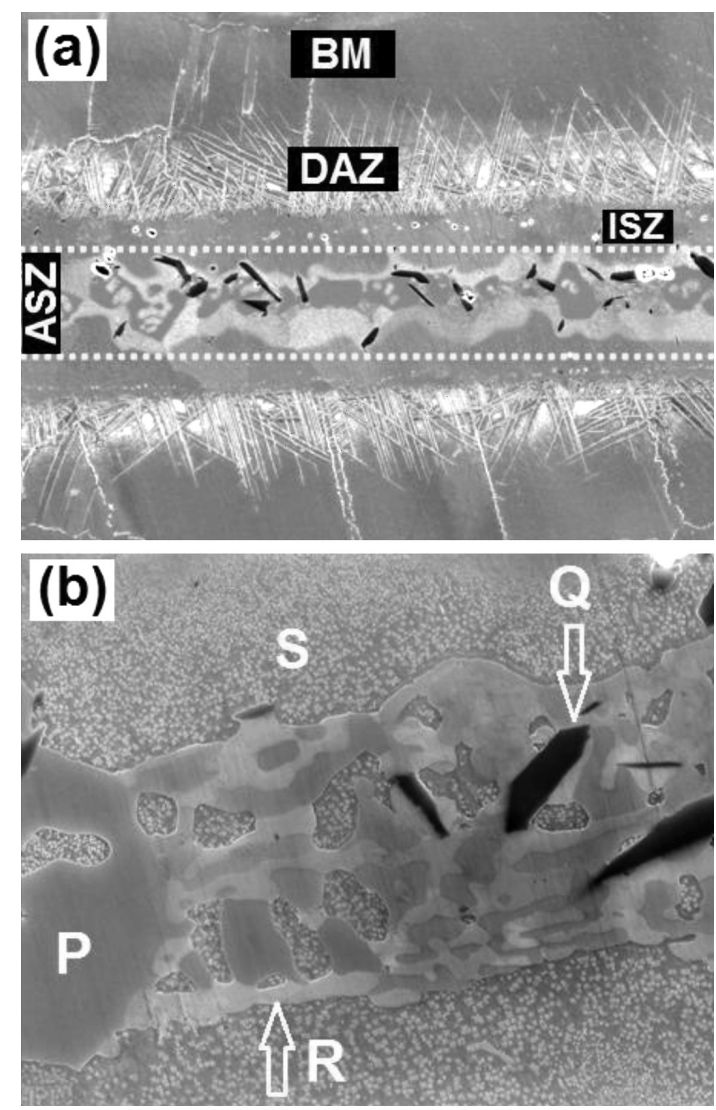

Figure 2: a) Typical overview of TLP bonded wrought IN718 with the partial-isothermal-solidification joint region, b) detailed view of ASZ: the microconstituents marked as $\mathrm{P}, \mathrm{Q}$ and $\mathrm{R}$ are Ni-rich boride, $\mathrm{Cr}$-rich boride and Ni-rich silicide. The zone marked as $\mathrm{S}$ is the eutectic gamma solid solution containing fine $\mathrm{Ni}_{3} \mathrm{Si}$ precipitates.

Slika 2: a) Značilen videz spojenih TLP-vzorcev IN718 s področjem delnega izotermnega strjevanja, b) detajl videza ASZ: mikrogradniki, označeni s $\mathrm{P}, \mathrm{Q}$ in $\mathrm{R}$ so $\mathrm{z}$ Ni bogati borid, s $\mathrm{Cr}$ bogati borid in $\mathrm{z} \mathrm{Ni}$ bogati silicid. Področje, označeno s S, je evtektična gama-raztopina, ki vsebuje drobne izločke $\mathrm{Ni}_{3} \mathrm{Si}$.

Table 1: Chemical compositions (amount fraction, $x / \%$ ) of different metallic constituents for various phases observed in the athermal solidification zone

Tabela 1: Kemijska sestava (množinski delež, $x / \%$ ) različnih kovinskih gradnikov v različnih fazah, opaženih v območju neizotermnega strjevanja

\begin{tabular}{|c|c|c|c|c|c|c|c|c|}
\hline Microconstituent/Element & $\mathrm{Ni}$ & $\mathrm{Cr}$ & $\mathrm{Fe}$ & $\mathrm{Si}$ & $\mathrm{Mo}$ & $\mathrm{Nb}$ & $\mathrm{Al}$ & $\mathrm{Ti}$ \\
\hline $\mathrm{P}$ & 84.05 & 6.53 & 3.53 & 0.95 & - & 3.55 & 1.38 & - \\
\hline $\mathrm{Q}$ & 13.42 & 79.32 & 1.40 & 0.10 & 2.63 & 3.00 & 0.13 & - \\
\hline $\mathrm{R}$ & 79.10 & 3.15 & 2.23 & 15.05 & 0.12 & 0.12 & 0.2 & 0.04 \\
\hline $\mathrm{S}$ & 77.04 & 7.61 & 4.64 & 9.62 & 0.21 & 0.52 & 0.14 & 0.22 \\
\hline
\end{tabular}


at $1050{ }^{\circ} \mathrm{C}$ for 10 min indicating a steep microstructural gradient in the joint area. Three distinct microstructural zones can be distinguished in the affected bonding area, namely:

- the isothermal solidification zone (ISZ),

- the athermal solidification zone (ASZ),

- the diffusion-affected zone (DAZ).

The ISZ is composed of a thin layer of the $\gamma$ solid solution formed at the solid/liquid interface towards the joint centerline due to isothermal solidification. As can be seen in Figure $\mathbf{2 b}$, the ASZ is composed of four distinct phases marked with $\mathrm{P}, \mathrm{Q}, \mathrm{R}$ and $\mathrm{S}$. Table $\mathbf{1}$ shows the EDS-SEM analysis of the phases formed in the ASZ. According to Table 1:

- $\mathrm{P}$ is a Ni-rich boride intermetallic formed during the cooling of the residual liquid.

- $\mathrm{Q}$ is a Cr-rich boride intermetallic formed during the cooling of the residual liquid.

- $\mathrm{R}$ represents Ni-rich the silicide eutectic microconstituents formed during the cooling of the residual liquid.

- $\mathrm{S}$ is the eutectic- $\gamma$ formed during the non-isothermal solidification of the residual liquid as part of the eutectic solidification product. This region contains extensive fine $\mathrm{Ni}_{3} \mathrm{Si}$ precipitates formed during the
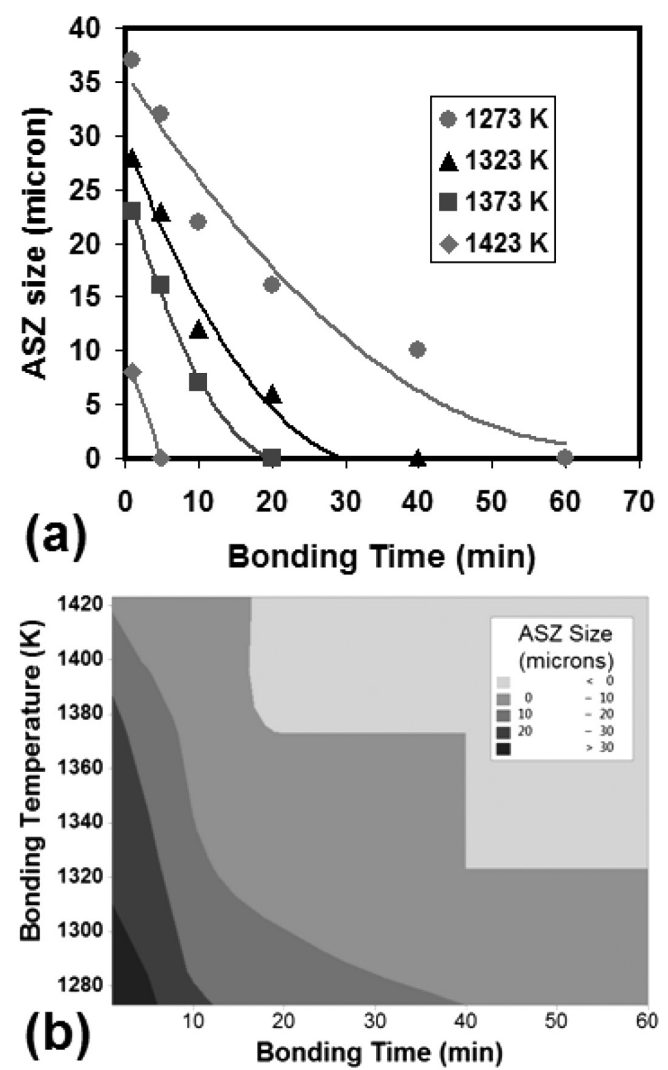

Figure 3: a) Effect of the bonding time and temperature on the ASZ size, b) contour plot of the ASZ size versus the bonding time and temperature

Slika 3: a) Vpliv časa in temperature spajanja na velikost ASZ, b) prikaz obrisa velikosti ASZ, glede na čas in temperaturo spajanja solid-state precipitation reaction during the cooling, not directly from the solidification of the remaining liquid.

According to the morphology of the phases in the ASZ, it can be concluded that they are formed during the eutectic-type reaction during the cooling of the liquid phase. Considering the brittleness of the intermetallic phases in the bonding condition when the isothermal solidification is not accomplished completely, the stress concentration associated with the eutectic microconstituents plays the key role in determining the joint strength. It was shown that the size of the athermal solidification zone (ASZ) is the controlling factor for the shear strength of the partially isothermally solidified TLP bonded IN718

\subsection{Effect of process parameters on isothermal solidi- fication progress}

The time required to obtain a eutectic-free joint centerline is the key parameter in designing a TLP bonding cycle. Studying the effects of the bonding parameters on the time required to ensure the completion of isothermal solidification can serve as the first step toward the optimization of the process parameters to obtain an isothermally solidified joint free of deleterious intermetallic formations in the joint centerline. Therefore, to investigate the effects of the bonding parameters on the isothermal solidification progress, bonding was carried out at the temperatures of $(1273,1323,1373$ and 1423) $\mathrm{K}$ with various durations. Taking the $\gamma$-solid solution/eutectic boundary as the solid/residual liquid interface at the end of each holding time, the average ASZ size was measured. Figure 3a shows the variation in the ASZ size with respect to the bonding time at various bonding temperatures. Figure $\mathbf{3 b}$ shows a contour plot of the ASZ versus the bonding time and temperature. As can be seen, the ASZ size decreases with the increasing bonding temperature and bonding time due to a larger diffusion of the melting-point-depressant

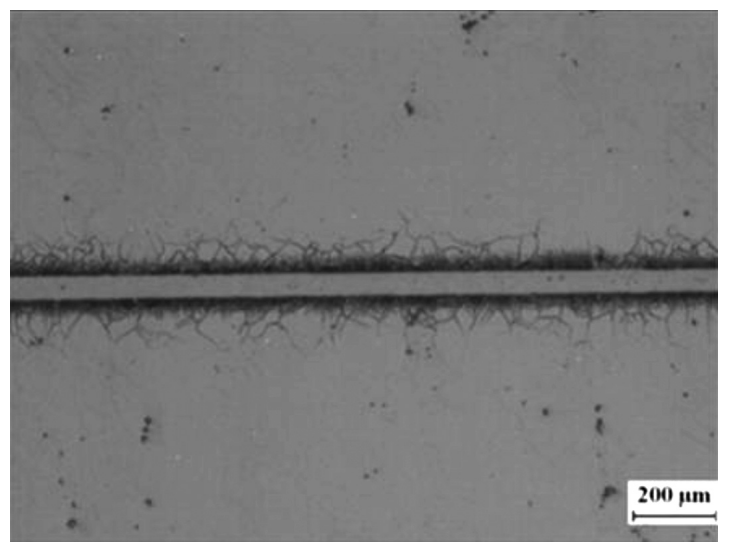

Figure 4: Typical eutectic-free joint indicating the completion of isothermal solidification

Slika 4: Značilen spoj brez evtektika, ki prikazuje dokončanje izotermnega strjevanja 
(MPD) elements into the base metal. When the bonding time was sufficient for the completion of isothermal solidification, a eutectic-free joint centerline was obtained (Figure 4). According to Figure 3, the time required to ensure the completion of isothermal solidification decreases as the bonding temperature increases.

In this section the progress of isothermal solidification is analyzed using the Larson-Miller normalization. The development of the Larson-Miller normalization starts by expressing the rate for a thermally activated process, $r$, as an Arrhenius-type equation ${ }^{10}$. The rate of isothermal solidification is equal to the rate of the solid/liquid movement during the bonding process that can be expressed as follows ${ }^{13}$ :

$$
r=\frac{\mathrm{d} X(t)}{\mathrm{d} t}=\frac{D}{\left(C_{\mathrm{L}}-C_{\mathrm{S}}\right)}\left(\frac{\partial C}{\partial t}\right)_{x=X(t)}
$$

where $D$ is the diffusivity of the MPD element in the $\mathrm{BM}, C_{\mathrm{L}}$ and $C_{\mathrm{S}}$ are the equilibrium liquidus and solidus, respectively, $(\partial C / \partial t)_{x=X(t)}$ is the gradient of the MPD
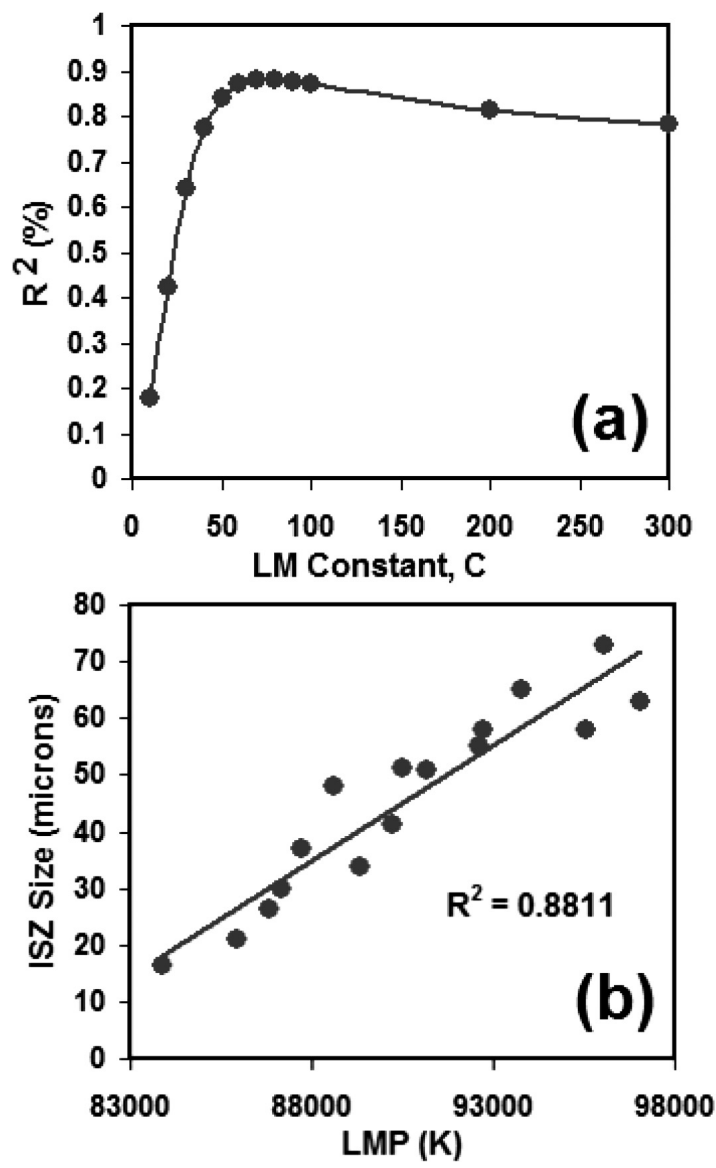

Figure 5: a) Coefficient of determination for fitting versus the Larson-Miller constant, $C$, b) ISZ size versus $L M P[T(70+\ln (t))]$ in TLP bonding of IN718/Ni-Cr-Fe-Si-B/IN718

Slika 5: a) Koeficient ujemanja z Larson-Millerjevo konstanto $C$, b) velikost ISZ v odvisnosti od $L M P[T(70+\ln (t))]$ in pri TLP-spajanju IN718/Ni-Cr-Fe-Si-B/ IN718 element at the solid/liquid interface and $X(t)$ is the liquid/solid interface position.

Since the diffusion coefficient is related to the temperature using an Arrhenius-type equation, the rate of isothermal solidification in a given time can be expressed as an Arrhenius-type equation:

$$
r=A \exp \left(-\frac{Q}{R T}\right)
$$

where $A$ is the pre-exponential factor, $Q$ is the activation energy, $R$ is the universal gas constant and $T$ is the temperature. Rearranging Equation (2) leads to the following equation:

$$
\frac{Q}{R}=T[\ln (A)-\ln (r)]
$$

Since the rate $r$ is inversely proportional to time $t$, Equation (3) can be further written as:

$$
\frac{Q}{R}=T[\ln (A)+\ln (t)]
$$

Equation (4) serves as the basis for the Larson-Miller parameter, the $L M P$ :

$$
L M P=\frac{Q}{R}=T[C+\ln (t)]
$$

with the Larson-Miller constant defined as $C=\ln A$.

The width of the ISZ was measured for each bonding time and temperature and the variation in the ISZ size versus the $L M P$ with various Larson-Miller constants $(C)$ was plotted. A linear trend line was used to fit the data to the $L M P$. The coefficient of determination $\left(R^{2}\right)$ was determined at each LM constant $(C)$. Figure 5a shows the variation in the coefficient of determination $\left(R^{2}\right)$ versus the LM constant. According to Figure 5a the best fitting was obtained when $C$ was 70 . Figure 5b shows the variation in the ISZ size versus $L M P=T[70+\ln (t)]$ confirming the following linear relationship between the ISZ size and the $L M P$ :

Size ISZ/ $\mu \mathrm{m}=0.0041 T_{\mathrm{B}}\left[70+\ln \left(t_{\mathrm{B}}\right)\right]-324.07$

where $T_{\mathrm{B}}(K)$ is the bonding temperature and $t_{\mathrm{B}}(\mathrm{h})$ is the bonding time.

Therefore, this normalization allowed the progress of isothermal solidification for different bonding times and at different bonding temperatures to be described with a common curve.

\section{CONCLUSIONS}

The understanding of isothermal solidification is of key importance in determining the mechanical performance of a transient-liquid-phase bonded joint. In this paper, the isothermal solidification during the TLP bonding of a wrought IN718 superalloy is studied and the results are analyzed using the Larson-Miller parameter. The following conclusions can be drawn from this study: 
1) When the bonding time in not sufficient for the isothermal solidification completion, the joint centerline contains a eutectic-type microconstituent that can degrade the mechanical properties of the joint.

2) The isothermal solidification time required to obtain a eutectic-free joint centerline is reduced as the bonding temperature increases from $1273 \mathrm{~K}$ to $1423 \mathrm{~K}$.

3 ) Based on the Larson-Miller parameters $(L M P)$, the TLP bonding parameter is defined as $T_{\mathrm{B}}\left[70+\operatorname{Ln}\left(t_{\mathrm{B}}\right)\right]$ to explore the effects of the bonding temperature $\left(T_{\mathrm{B}}\right)$ and the bonding time $\left(t_{\mathrm{B}}\right)$ on the isothermal solidification progress. It was found that there is a direct linear relationship between the LMP and the isothermal-solidification-zone size.

\section{Acknowledgement}

The authors would like to thank the Dezful Branch, Islamic Azad University for providing the financial support of this work under the research project entitled: "Investigation on the effect of chemical composition of filler metal on the phase transformations and mechanical properties of diffusion brazed IN718 nickel based superalloy".

\section{REFERENCES}

${ }^{1}$ A. Milosavljevic, S. Petronic, S. Polic-Radovanovic, J. Babic, D. Bajic, Mater. Tehnol., 46 (2012) 4, 411-417

${ }^{2}$ R. Sunulahpašić, M. Oruč, M. Hadžalić, M. Rimac, Mater. Tehnol., 46 (2012) 3, 263-267

${ }^{3}$ A. Semenov, S. Semenov, A. Nazarenko, L. Getsov, Mater. Tehnol., 46 (2012) 3, 197-203

${ }^{4}$ W. F. Gale, D. A. Butts, Sci. Technol. Weld. Joining, 9 (2004), 283-300, doi:10.1179/136217104225021724

${ }^{5}$ I. Tuah-Poku, M. Dollar, T. B. Massalski, Metall. Trans. A, 9 (1988), 675-686, doi:10.1007/bf02649282

${ }^{6}$ M. Pouranvari, A. Ekrami, A. H. Kokabi, Mater. Sci. Eng. A, 568 (2013), 76-82, doi:10.1016/j.msea.2013.01.029

${ }^{7}$ D. S. Duvall, W. A. Owczarski, D. F. Paulonis, Weld. J., 53 (1974), 203-214

${ }^{8}$ M. Pouranvari, A. Ekrami, A. H. Kokabi, Mater. Tehnol., 47 (2013) 5, 593-599

${ }^{9}$ M. Pouranvari, Mater. Tehnol., 48 (2014) 1, 113-118

${ }^{10}$ F. R. Larson, J. A. Miller, Trans. ASME, 74 (1952), 765-775

${ }^{11}$ S. Venkadesan, A. K. Bhaduri, P. Rodriguez, K. A. Padmanabhan, J. Nucl. Mater., 186 (1992), 177-184, doi:10.1016/0022-3115(92) 90332-f

${ }^{12}$ A. M. Limarga, J. Iveland, M. Gentleman, D. M. Lipkin, D. R. Clarke, Acta Mater., 59 (2011), 1162-1167, doi:10.1016/j.actamat. 2010.10.049

${ }^{13}$ Y. Zhou, W. F. Gale, T. H. North, Int. Mater. Rev., 40 (1995), 181-196, doi:10.1179/imr.1995.40.5.181 